\title{
Vertical farming systems bring new considerations for pest and disease management
}

\author{
by Roberts, J.M., Bruce, T.J., Monaghan, J.M., Pope, \\ T.W., Leather, S.R. and Beacham, A.M.
}

Copyright, publisher and additional information: this is the author accepted manuscript. The final published version (version of record) is available online via Wiley. This article may be used for non-commercial purposes in accordance with Wiley Terms and Conditions for Self-Archiving.

Please refer to any applicable terms of use of the publisher.

DOI: $\underline{\text { https://doi.org/10.1111/aab.12587 }}$

Harper Adams University

Roberts, J.M., Bruce, T.J., Monaghan, J.M., Pope, T.W., Leather, S.R. and Beacham, A.M. Vertical farming systems bring new considerations for pest and disease Management. Annals of Applied Biology. 


\section{Vertical Farming Systems Bring New Considerations for Pest and Disease Management}

SUMMARY: Vertical Farming is an emerging area of food production that aims to provide sustainable intensification of agriculture by maximising the obtainable yield per unit area of land. This approach commonly utilises stacked horizontal levels of crop growth in glasshouse or controlled environment (CE) facilities. Vertical Farming has, however, received relatively little scientific investigation to date, meaning that important factors such as economic feasibility, system design, and optimisation of production methods are still being evaluated. Vertical Farming methods bring additional considerations for the effective management of pests and diseases compared with conventional protected horticulture, such as movement of both pest and beneficial insects between growth levels. This article aims to provide a perspective on the positive and negative issues facing pest and disease control in Vertical Farming systems. We highlight important considerations for system optimisation and areas for future investigation.

KEYWORDS: Vertical farming, pest, disease, management, horticulture, urban agriculture 


\section{INTRODUCTION}

The world population is estimated to reach 9.7 billion by 2050 (United Nations, 2015), which, together with the effects of climate change, will place pressure on the agri-food industry to provide higher yields while also minimising land and resource use with the aim of increasing sustainability (Abou-Hussain, 2012; Wheeler and von Braun, 2013; Rosenzweig et al., 2014; Al-Chalabi, 2015; Godfray et al 2010). To provide global food security for future generations, alternative food production systems are being investigated. One such system is vertical farming, an initiative that encompasses a variety of food production methods aiming to increase the quantity of crop produced per unit area of land by 'farming up rather than out'. Although thought of as a relatively recent development, suggestions of such agricultural methods were made in the early $20^{\text {th }}$ Century (Al-Kodmany, 2018). Current vertical farming, however, uses the latest technology and usually takes place within controlled environment (CE) facilities or glasshouses with glass or plastic outer walls.

Approaches to vertical farming are numerous and varied, including green walls where produce is grown on a vertical or inclined surface and growth around vertically-orientated cylinders. However, the most commonly used approach comprises stacked horizontal beds of soil-based or soil-free cultivation (Beacham et al., 2019). Vertical farming is a rapidly expanding industry (Kopf, 2017) that is receiving much interest and investment from a range of different parties and, perhaps due to its close links to urban agriculture, is lauded by some as the future of food production (Despommier, 2010). Evidence of the growth in vertical farming can be seen in countries such as Japan, currently the world leader in the sector (Kozai, 2013), where the number of farms has grown from 35 in 2009 to over 150 in 2017 (Hayashi, 2017). Despite their increasing use, vertical farming systems have received little in the way of rigorous scientific investigation to date (Al-Chalabi, 2015; Eigenbrod and Gruda, 2015; Mok et al., 2014; Pinstrup-Andersen, 2018; Beacham et al., 2019). Consequently, there are several important questions that remain to be addressed to help determine the viability of vertical farming for meaningful food production in the future. 
As a new and emerging area of agriculture that utilises novel production systems, vertical farming raises new questions to age-old issues such as the effective management of diseases and pests, which cause damage through herbivory and vector plant pathogens (Whitfield et al., 2015; Sarwar and Sarwar 2018). Some considerations will be familiar from conventional protected horticultural systems, but the innovative approaches of vertical farming may provide new challenges to producing healthy crops and therefore high-quality produce. Furthermore, with crop selection encompassing a large group of horticultural fresh produce species (Beacham et al., 2018), vertical farming requires the control of a very wide range of pests and diseases. Here we will focus on the considerations and opportunities for pest and disease management in stacked horizontal vertical farming systems, which use vertically stacked arrangements of horizontal growth beds in glasshouse or CE facilities and represent the most common system used globally (Beacham et al., 2019).

\section{Pest and Disease Management in Vertical Farming}

\section{Pest and Disease Access}

Proponents of vertical farming and urban agriculture systems claim that their use will prevent all insect and disease access and eliminate any pest control requirements due to their situation in protective structures (Despommier, 2013). While glasshouses and, particularly, CE systems do restrict the entry of pests and diseases, they cannot realistically be expected to entirely prevent the occurrence of pests and diseases in a crop. Indeed, it is considered almost impossible to exclude many pests and pathogens from glasshouses (Jarvis, 1992; Goodman and Minner, 2019). Glasshouse-based vertical farms would be expected to encounter the same pest and disease pressure as conventional protected horticulture, while those utilising CE facilities will still be at risk.

Introduction of arthropod pests or plant diseases into protected horticulture systems can occur through several mechanisms, including: accidental contamination via employees or seed; inadequate phytosanitation protocols; or poorly maintained glasshouse and CE 
structures. Perhaps the most likely mechanism of introduction is through ventilation systems and doorways (Figure 1A). The resulting combination of disease and pest damage commonly results in significant economic losses in glasshouse-grown crops. Air filters and airlock-based systems with decontamination protocols such as the use of air showers can help to minimise pest entry but may provide difficulties when removing produce for sale as large entry/exit spaces are required. Even so, the small size of microorganisms, such as fungal spores (for example, conidia of Bremia lactucae, the causal agent of downy mildew in lettuce), arthropod pests (such as two-spotted spider mite (Tetranychus urticae)) and insects (such as western flower Thrips (Frankliniella occidentalis)) facilitates their access into even the most wellmaintained 'pest proof' protected growing systems. Vertical farm operators should therefore be prepared for the eventuality of pest and/or pathogen access and consider the factors that can influence their proliferation and control in such systems.

\section{Effects of Growth Conditions}

Once inside, the designs of vertical farming systems present their own unique challenges to pest and disease management. Many vertical farming systems use stacked horizontal growing surfaces contained within a high-sided glasshouse or CE facility, providing the possibility of vertical as well as horizontal spread of pests. Within glasshouses, there may be steep vertical temperature gradients (Hanan 1958; Carpenter and Bark 1967a, b), with a relatively large headspace required to provide as uniform a temperature as possible (Jarvis, 1992). The increased height of vertical farming growth systems compared to conventional facilities could present large gradients of temperature, humidity, and light availability (Figure 1B-C) from the top to the bottom of the facility. Whilst air circulation is essential to provide uniform temperatures, humidity and carbon dioxide concentrations for plant growth and to aid control of many diseases (Jarvis, 1992), air circulation may also facilitate the spread of pests and diseases within the crop. Spores of many plant pathogenic fungi, such as grey mould (Botrytis cinerea) (Figure 1D), are known to be dispersed by air currents (Li and LaMondia, 2010, Figure 1D). Similarly, arthropod pests, such as the two-spotted spider mite (Tetranychus 
urticae) also disperse via air currents to find host plants or mates (Yano, 2004). Stacked horizontal vertical farming system dimensions not only present challenges in producing a uniform crop but may also lead to a heterogeneous distribution of pests and disease. The different temperature optima of different disease-causing micro-organisms (Jarvis, 1992), could mean that tailored management approaches may be required for each growing level contained within the system.

Despite the increased level of environmental control offered by glasshouse and CE growth systems, residual spatial heterogeneity in growth conditions could lead to a portion of the crop experiencing sub-optimal environmental conditions. Such conditions can lead to plant abiotic (environmental) stress which, in turn, affects the ability of disease-causing microorganisms to infect the crop. The simultaneous occurrence of both abiotic and biotic (biological) stress can have either a positive or negative interaction depending on the timing, nature and severity of each stress. For example, non-optimal high or low temperatures can lower the resistance of plant hosts to bacterial, viral, fungal and nematode pathogens (Szittya et al., 2003; Atkinson and Urwin, 2012; Bostock et al., 2014; Suzuki et al., 2014). Positive interactions between abiotic and biotic stress, meanwhile, include increased resistance to $B$. cinerea in tomato associated with drought stress (Achuo et al., 2006).

In protected growth systems, transpiration from the crop and evaporation from exposed hydroponic nutrient solution causes an increase in humidity, which can aid crop growth (Maher and O'Flaherty, 1973; Cockshull 1985) but also provides suitable conditions for the proliferation of pathogens (including powdery mildews (Whipps and Budge, 2000) and B. cinerea (Elad and Shtienberg, 1995)). In stacked vertical farming systems, humidity buildup in the restricted airspace between shelves may provide conditions conducive to disease development (Figure 1E). High humidity also increases the activity of insects (Hussey et al., 1967), which could lead to increased pest damage. However, such conditions may also increase the efficacy of arthropod and fungal biocontrol measures, such as the chalcidoid wasp Encarsia formosa, used to treat whitefly (Trialeurodes vaporariorum), and entomopathogenic fungi, such as Beauveria bassiana (Luz and Fargues, 1999). By contrast, 
low humidity can also favour certain pests, including spider mites (Tetranychus urticae) (Resh, 1998). Proper control of humidity is therefore key to minimising pests and diseases in protected systems such as vertical farms.

Condensation forming on the undersides of stacked growing levels could generate water droplets that may fall back onto the surface of plants growing on the level below (Figure 1F). Such droplets could promote the spread of disease through dispersal of fungal spores (McCartney, 1994) or bacteria (Butterworth and McCartney, 1991) as has been found for droplets falling from glasshouse roofs or overhead irrigation (Beaumont et al., 1936; Yarwood 1956; Kamerman 1975; Hirano and Upper 1983). Indeed, overhead irrigation is discouraged to prevent spread of Botrytis and Peronospora spores (Jarvis, 1992). Therefore, water droplets falling between levels in vertical farming systems due to the condensation of humidity, from irrigation or growing medium could act as a route for encouraging disease spread. Similarly, insects or fungal spores could fall from higher to lower shelves under the influence of gravity alone, acting to encourage the spread of infection or damage from upper to lower shelves even without the aid of water droplets (Figure 1G).

It should also be considered that, for chemical pest control methods that use insecticides and fungicides, settlement of spray droplets under the influence of gravity could lead to the accumulation of higher levels of the pesticide on lower levels, potentially exceeding regulatory thresholds, increased treatment intervals prior to harvest or phytotoxicity.

\section{Movement of insects and adoption of biocontrol}

For flightless pests, the separation of growth levels could prove beneficial in reducing their ease of movement across the entire crop (Figure $1 \mathrm{H})$ but could also mean that flightless biocontrol agents such as the predatory mite Phytoseiulus persimilis are unable to move easily between levels. In this scenario growers may be required to use higher numbers of mites to tackle pest problems, at increased cost compared to conventional growing systems as each

level in the system will need to be treated separately (Figure 1J). This could potentially be 
addressed by introducing 'bridges' between growing levels to facilitate biocontrol movement, though this has potential to also be exploited by pests.

For biocontrol agents that can fly, there is a major advantage of being in a protected environment compared to an outdoor one because released insects are kept within the structure and cannot fly off elsewhere. This partly explains the higher adoption of biocontrol in conventional horizontal protected crops compared to outdoor crops (Paulitz and Bélanger, 2001). It is likely that biocontrol will be a major opportunity for pest management in vertical farming systems. Vertical farming is amenable to provide structural features such as banker plants (Frank, 2010) that could be used to maintain populations of biocontrol agents.

\section{Hydroponic Vertical Farming Systems}

Many vertical farming approaches utilise hydroponic growing systems. Such systems bring further considerations for disease management. Many microorganism species have been found in recirculating hydroponic systems, where it is normal for fungi such as Pythium to multiply and spread (Vanachter et al., 1983). The hydroponic system may however, also lack sufficient microorganism content and diversity to compete with pathogenic species (Zinnen, 1988). Close control of system sanitisation and microbiome is therefore required to

minimise disease development (Figure 1I). The relatively small volume of nutrient solution in nutrient film technique (NFT) systems, can, provide easier draining, flushing and cleaning if disease occurs (Hanan, 1998). Water treatment systems such as UV irradiation, ozone, ultrafiltration or heat treatment can be used for cleaning of hydroponic solution (Jarvis, 1992) and may help reduce disease occurrence. While these issues are relevant to hydroponic culture in general, they could be exacerbated by the large and complex hydroponic systems required in some vertical farming units. However, multi-level vertical farming systems may provide a useful opportunity to isolate nutrient solution flow to and from each level to restrict any nutrient solution-associated disease outbreaks to a single level. In addition to nutrients it may also be possible to add plant protection products or biostimulants to hydroponic growing systems to aid pest and disease control. 


\section{Effects on Semiochemical Communication}

Interactions between organisms are mediated through the perception of visual, tactile, auditory, or chemical information from their environment (de Boer and Dicke, 2005). Those chemical compounds that relay information, known as semiochemicals, have a diverse array of functions from mate location to predator avoidance (Mori, 2010). Semiochemicals can be exploited for integrated pest management (IPM) and synthetic versions are often used for pest monitoring, pest trapping, or mating disruption purposes (Heuskin et al. 2011). Vertical farming units may be well suited to mating disruption as the protected environment would prevent mated females invading from outside the treated area. The release rates of synthetic semiochemicals is influenced by environmental conditions (e.g. van der Kraan and Ebbers, 1990; Bradley et al., 1995; Torr et al., 1997), which could be altered in vertical farming systems that have different temperature, humidity or airflow patterns. The more controlled, less windy conditions of indoor environments may improve prospects for application of semiochemicals. Conversely, a temperature gradient within a vertical farming system from top to bottom, if not carefully managed, may result in a gradient of semiochemical release and reduces its efficacy through the system. Increased humidity has been shown to decrease semiochemical release rates when formulated in alginate (Heuskin et al., 2012), whilst increased airflow reduces semiochemical concentration and therefore efficacy (Jain and Bhargava, 2007) as concentration is an important factor for olfactory recognition by invertebrates (Bruce et al., 2005). For synthetic semiochemicals to be deployed effectively within vertical farming systems it is important to consider the system design, environmental conditions, and how the semiochemical is deployed. There are opportunities to introduce semiochemical dispensers into the design of vertical farming structures.

\section{Effects of Lighting}

Shading of the crop from levels of the growth system arranged above is an issue addressed in the design of many vertical farming systems. Adequate illumination is required 
not only for optimal growth of the crop, but the quality and quantity of available light also influences the response of plants to pests and pathogens, with crops grown in low light often being more susceptible to disease (reviewed by Roberts and Paul, 2006). For example, full sun has been shown to reduce herbivory in many species, particularly for leaf-chewing insects, but not in all cases (Roberts and Paul, 2006), while shade can promote infection by a range of pathogens (Pennypacker, 2000).

To offset decreased light levels found in the lower growing levels, many vertical farming systems use artificial lighting to provide either supplementary (in the case of glasshouses) or the entire (in the case of CE facilities) illumination for the crop. High-efficiency LED is frequently used as it provides a relatively low energy use requirement, the output spectrum can be tailored to the needs of the crop species being produced and their low heat output allows them to be placed close to the crop (Massa et al., 2008), for example between the levels of a vertical farming system (Figure 1J). LED illumination wavelength could however, also affect insect behaviour and/or pathogen growth and development and consequently alter approaches to their management (Roberts and Paul, 2006; Johansen et al., 2011). Artificial light and its spectral composition is expected to influence factors including orientation, host location, predation and dispersion behaviours in addition to reproduction, development and survival in both pests (e.g. the thrips Frankliniella occidentalis, which is attracted to blue light (Chen et al., 2004), whilst Frankliniella schulzei is attracted to red (Yaku et al., 2007)) and biocontrol agents (illumination with red and blue light may reduce prey visibility for ladybirds (Harmon et al., 1998) and red/blue light ratio alters population dynamics of the parasitoid wasp Aphidius ervi (Cochard et al., 2019)) (reviewed in Johansen et al., 2011). This also raises the possibility of using artificial lighting as part of an IPM control strategy through increased attraction to traps, disruption of host detection, use of directly harmful wavelengths and manipulation of circadian or photoperiod responses (Johansen et al., 2011). Red/blue LED lighting also can make visualising the colour green more difficult, potentially increasing the difficulty of pest and disease monitoring. This could be overcome by incorporating a small amount of white light. 
Light quality has been also shown to affect disease development. The spectral composition of LED light influences disease development arising from virus, fungal and bacterial sources (Schuerger and Brown, 1997). In the case of fungi, the inhibition of sporulation and germ tube growth by light is strongly wavelength-dependent, for example, near UV light induces and blue light inhibits sporulation in B. cinerea (Hite 1973; Peterson et al., 1988). Enhancing relative blue light levels or reducing UV irradiation through screening can help reduce disease in some cases, although foliage grown under reduced UV-B irradiation can often present a more attractive food source for herbivores (Roberts and Paul, 2006). In contrast, red light has been found to improve resistance, for example, to the leaf spot fungus Alternaria tenuissima in broad bean (Vicia faba) (Rahman et al., 2003) and powdery mildew (Sphaerotheca fuliginea) in cucumber (Cucumis sativus) (Wang et al., 2010). The effect of light on pests and diseases could occur by affecting leaf physical properties such as water content, mechanical toughness and trichome density, leaf chemical content, quality of the host as a food resource and host defence responses (Roberts and Paul, 2006). The choice of artificial illumination spectrum for vertical farming systems therefore must consider implications not only for the crop but also for pest and pathogen behaviour.

\section{Plant density}

One of the main aims of vertical farming is to enable production of higher yields of crops per unit area of land used. However, in optimising the number of plants that can be grown on any given building footprint, regard to plant spacing should be made as plant density is an important factor in pest and disease management due to the effect it has on the surrounding plant microclimate (Bravenboer, 1974; Burdon and Chivers, 1982) and therefore to disease development and spread (Burdon et al., 1989). To prevent the spread of disease entirely, the spacing of plants would need to be unrealistically and prohibitively large (Burdon and Chivers, 1982; Thresh, 1982). Therefore, the aim of producing as much crop per unit area must be balanced against plant overcrowding for good crop growth and health (Figure 1K). 
Rotating Vertical Farming Systems

To compensate for gradients in growth condition parameters such as temperature and light level, some vertical farming systems incorporate rotating systems of shelves that aim to provide a more even growth environment for each level of planting. Such systems bring additional considerations for pest and disease management. The movement of shelving could aid dispersal of fungal spores, bacteria and insects through mechanical disturbance of plants and water droplets, generation of additional air currents or by providing more opportunities for pests to fall from one shelf to another. The increased level of automation present in these and similar vertical farming systems may however, help to reduce the problem of disease spread via human labour if the design and cleaning of robotic management and harvesting systems are carefully considered. Research would be required to establish biocontrol and pollinator efficacy in vertical farming systems.

\section{Conclusion}

Vertical farming represents a novel approach to food production, building on methodological and technical innovations in protected growth systems. Knowledge of pest and disease control in conventional protected horticulture is well established, however, vertical farms bring additional considerations which are specific to the optimal operation of such systems. It is likely that challenges have been underestimated, particularly in news items claiming that vertical farming has near zero pest or disease risk. Whilst restricting pest and pathogen ingress, vertical farming systems, particularly those in glasshouses, are unlikely to eliminate all infection risk, rendering infection or damage an eventuality. Growers should therefore consider the control requirements specific to such growth systems and be prepared to act appropriately in the event of a pest or disease outbreak.

Vertical farming systems have vulnerabilities to pests but there are also unique opportunities to provide new crop protection features in these environments. The adoption of standard operating procedures (SOPs) for control of staff and equipment movement and sterility, together with the use of high-resolution sensor-based monitoring of growth conditions 
are existing means to aid pest and disease control in vertical farms. The potential exists to enhance this control through adoption of IPM-based strategies encompassing artificial lightbased manipulation of pest and disease behaviour, combined with sophisticated nutrient solution treatment, control and isolation systems and semiochemical employment. Such methods would need to be tailored to each vertical farm type and to each growth level separately to enable maximal efficacy and minimised pest and disease risk. As with protected horizontal farming systems, vertical farming systems are well-suited to augmented biological control practices (i.e. releasing large numbers of mass-reared beneficial arthropods). Biological control can be extremely effective in controlling arthropod pests, with growers in the Almeria region of Spain almost completely replacing insecticides with biological control (Calvo et al., 2015). Vertical farming systems present new challenges for deploying biological control agents but also provide new opportunities to develop new deployment technologies.

However, there is a current lack of rigorous scientific investigation of pest and diseases in vertical farming systems. We suggest several key areas for filling knowledge gaps, namely: 1) What is the effect of gradients in environmental conditions from the top to the base of vertical farms on crop growth and interaction with pest and pathogen development and control measures? 2) What is the potential of disease, pest and biocontrol transfer between different growth levels in static and rotating vertical farm systems? 3) What is the role of humidity build up between growth levels regarding crop growth and pathogen dispersal? 4) How can pest management features, e.g. for enhancing sanitation and biological control, be built into the design of vertical farming units. Outputs of such research will help to determine the efficacy of pest and disease control strategies for vertical farming and ultimately its success in the food production supply chain and ability to optimise land use to feeding a growing world.

\section{REFERENCES}

Abou-Hussain, S. D. (2012). Climate change and its impact on the productivity and quality of vegetable crops. Journal of Applied Science Research, 4359-4383. 
Achuo, E. A., Prinsen, E., Hofte, M. (2006). Influence of drought, salt stress and abscisic acid on the resistance of tomato to Botrytis cinerea and Oidium neolycopersici. Plant Pathology, $55,178-186$.

Al-Chalabi, M. (2015). Vertical Farming: Skyscraper sustainability? Sustainable Cities and Society, 18, 74-77.

Al-Kodmany, K. (2018). The vertical farm: a review of developments and implications for the vertical city. MDPI Buildings, 8, 1-36.

Association for Vertical Farming (2016). The State of Vertical Farming. Available at: https://files.acrobat.com/a/preview/eb22c193-290f-40e4-ae65-ca42384786c6

Atkinson, N. J. and Urwin, P. E. (2012). The interaction of plant biotic and abiotic stresses: from genes to the field. Journal of Experimental Botany, 63, 3523-3543.

Baker, K. L., Dickinson, M., Findley, T. M., Gire, D. H., Louis, M., Suver, M. P., Verhagen, J. V., Nagel, K. I and Smear, M. C. (2018). Algorithms for olfactory search across species. Journal of Neuroscience, 48, 9383-9289.

Beacham, A. M., Vickers, L. H., Monaghan, J. M. (2019). Vertical farming: a summary of approaches to growing skywards. Journal of Horticultural Science and Biotechnology, 94, 277283.

Beaumont, A., Dillon Weston, W. A. R., Wallace, E. R. (1936). Tulip fire. Annals of Applied Biology, 23, 57-88.

Bostock, R. M., Pye, M. F., Roubtsova, T. V. (2014). Predisposition in plant disease: exploiting the nexus in abiotic and biotic stress perception and response. Annual Review of Phytopathology, 52: 517-549. 
Bradley, S. J., Suckling, D. M., McNaughton, K. G., Wearing, C. H. and Karg, G. (1995). A temperature dependent model for predicting release rates of pheromones from polyethelene tubing dispensers. Journal of Chemical Ecology, 21, 745-760.

Bravenboer, L. (1974). Pest and disease control in glasshouses in north-west Europe. Outlook on Agriculture, 8, 95-99.

Bruce, T. J. A., Wadhams, L. J. and Woodcock, C. M. (2005). Insect host location: a volatile situation. Trends in Plant Science, 10, 269-274.

Burdon, J. J., Jarosz, A. M., Kirby, G. C. (1989). Pattern and patchiness in plant-pathogen interactions - causes and consequences. Annual Review of Ecology and Systematics, 20, 119-136.

Burdon, J. J. and Chivers, G. A. (1982). Host density as a factor in plant disease ecology. Annual Review of Phytopathology, 20, 143-166.

Butterworth, J. and McCartney, H. A. (1991). The dispersal of bacteria from leaf surfaces by water splash. Journal of Applied Bacteriology, 71, 484-496.

Calvo, F.J., Knapp, M., van Houten, Y.M., Hoogerbrugge, H. and Belda, J.E. (2015) Amblyseius swirskii: what made this predatory mite such a successful biocontrol agent? Experimental and Applied Acarology, 65, 419-433.

Carpenter, W. J. and Bark, L. D. (1967)a. Temperature patterns in greenhouse heating. I. Introduction. Florists' Review, 139, 43-45.

Carpenter, W. J. and Bark, L. D. (1967)b. Temperature patterns in greenhouse heating. II. Temperature patterns and steam coils. Florists' Review, 139, 21-22.

Chen, T. Y., Chu, C. C., Fitzgerald, G., Natwick, E. T., Henneberry, T. J. (2004). Trap evaluations for thrips (Thysanoptera: Thripidae) and hoverflies (Diptera: Syrphidae). Environmental Entomology, 33, 1416-1420. 
Cochard, P., Galstian, T., Cloutier, C. (2019). The proportion of blue light affects parasitoid wasp behaviour in LED-extended photoperiod in greenhouses: Increased parasitism and offspring sex ratio bias. Biological Control, 133, 9-17.

Cockshull, K.E. (1985). Greenhouse climate and crop response. Acta Horticulturae, 174, 285292.

Despommier, D. (2010). The Vertical Farm: Feeding the World in the $21^{\text {st }}$ Century. New York: Picador.

Despommier, D. (2013). Farming up the city: the rise of urban vertical farms. Trends in Biotechnology, 31, 388-389.

Du, Y., Poppu. G. M., Powell, W., Pickett, J. A., Wadhams, L. J. and Woodcock, C. M. (1998). Identification of semiochemicals released during aphid feeding that attract parasitoid Aphidius ervi. Journal of Chemical Ecology, 24, 1355-1368.

Eigenbrod, C. and Gruda, N. (2015). Urban vegetable for food security in cities. A review. Agronomy and Sustainable Development, 35, 483-498.

Elad, Y. and Shtienberg, D. (1995). Botrytis cinerea in greenhouse vegetables: chemical, cultural, physiological and biological controls and their integration. Integrated Pest Management Reviews, 1, 15-29.

Frank, S.D. (2010) Biological control of arthropod pests using banker plant systems: past progress and future directions. Biological control, 52: 8-16.

Godfray, H. C. J., Beddington, J. R., Crute, I. R., Haddad, L., Lawrence, D., Muir, J. F., Pretty, J., Robinson, S., Thomas, S. M. and Toulmin, C. (2010). Food security: the challenge of feeding 9 billion people. Science, 327, 812-818. 
Goodman, W. and Minner, J. (2019). Will the urban agricultural revolution be vertical soilless? A case study of controlled environment agriculture in New York City. Land Use Policy, 83, 160-173.

Hanan, J. J. (1958). Air movement and temperature control. Colorado Flower Growers Association Research Bulletin, 188, 1-3.

Hanan. J. J. (1998), Chapter 5 'Water'. In: Greenhouses: Advanced Technology for Protected Horticulture. CRC Press, Boca Raton, FL.

Harmon, J., Losey, J. E., Ives, A. R. (1998). The role of vision and colour in the close proximity foraging behaviour of four coccinellid species. Oecologia, 115, 287-292.

Hauashi, E. (2017). Japan Special Report: Plant Factories with Artificial Light (PFAL). Available at: https://urbanagnews.com/blog/japan-special-report-plant-factories-with-artificiallight-pfal/.

Heuskin, S., Lorge, S., Lognay, G., Wathelet, J. P., Bera, F. Leroy, P., Haubruge, E., Brostaux, Y. (2012). A semiochemical slow-release formulation in a biological control approach to attract hoverflies. Journal of Environmental Ecology, 3, 72-85.

Heuskin, S., Verheggen, F. J., Haubruge, E., Wathelet, J-P. and Lognay, G. (2011). The use of semiochemical slow-release devices in integrated pest management strategies. Biotechnologie, Agronomie, Societe et Environnement, 15, 459-470.

Hirano, S. S. and Upper, C. D. (1983). Ecology and epidemiology of foliar bacterial plant pathogens. Annual Review of Phytopathology, 21, 243-269.

Hite, R. E. (1973). The effect of irradiation on the growth and asexual reproduction of Botrytis cinerea. Plant Disease Reports, 57, 131-135.

Hussey, N. W., Read, H. W., Hesling, J. J. (1967). The pests of protected cultivation. Elsevier, New York. 
Jain. P. C. and Bhargava, M. C. Eds. (2007). Entomology: Novel Approaches. New India Publishing Agency, New Delhi.

Jarvis, W. R. (1992). Managing disease in greenhouse crops. APS Press, St Paul, MN.

Johansen, N. S., Vanninen, I., Pinto, D. M., Nissinen, A. I., Shipp, L. (2011). In the light of new greenhouse technologies: 2. Direct effects of artificial lighting on arthropods and integrated pest management in greenhouse crops. Annals of Applied Biology, 159, 1-27.

Kamerman, W. (1975). Biology and control of Xanthomonas hyacinthi in hyacinths. Acta Horticulturae, 47, 99-105.

Kopf, A. (2017). State of Indoor Farming. Available at: www.agrilyst.com/stateofindoorfarming2017/\#cta.

Kozai, T. (2013). Resource use efficiency of closed plant production system with artificial light: Concept, estimation and application to plant factory. Proc Jpn Acad Ser B Phys Biol Sci, 10, 447-461.

Li, D. W. and LaMondia, J. (2010). Airborne fungi associated with ornamental plant propagation in greenhouses. Aerobiologia, 26, 15-28.

Maher, M. J. and O'Flaherty, T. (1973). An analysis of greenhouse climate. Journal of Agricultural Engineering Research, 18, 197-203.

Massa, G. D., Kim, H. H., Wheeler, R. M., Mitchell, C. A. (2008). Plant productivity in response to LED lighting. HortScience, 43, 1951-1956.

McCartney, H. A. (1994). Dispersal of spores and pollen from crops. Grana, 33, 76-80.

Mok, H-F., Williamson, V. G., Grove, J. R., Burry, K., Barker, S. F., Hamilton, A. J. (2014). Strawberry fields forever? Urban agriculture in developed countries: a review. Agronomy and Sustainable Development, 34, 21-43. 
Mori, K. (2010). Pheromones in chemical communication. In: A. Herrmann Ed. The Chemistry and Biology of Volatiles. London, John Wiley and Sons Ltd: 123-147.

Paulitz, T.C. and Bélanger, R.R. (2001) Biological control in greenhouse systems. Annual review of phytopathology, 39: 103-133.

Pennypacker, B. W. (2000). Differential impact of carbon assimilation on the expression of quantitative and qualitative resistance in alfalfa (Medicago sativa). Physiological and Molecular Plant Pathology, 57, 87-93.

Peterson, M. J., Sutherland, J. R., Tuller, S. E. (1988). Greenhouse environment and epidemiology of grey mould of container-grown Douglas fir seedlings. Canadian Journal of Forest Research, 18, 974-980.

Pinstrup-Andersen, P. (2018). Is it time to take vertical indoor farming seriously? Global Food Security, 17, 233-235.

Rahman. M. Z., Honda, Y., Arase, S. (2003). Red-light-induced resistance in broad bean (Vicia faba L.) to leaf spot disease caused by Alternaria tenuissima. Phytopathology, 151, 86-91.

Resh, H. M. (1998). Chapter 12 'Plant Culture'. In: Hydroponic Food Production. Fifth Edition. Woodbridge Press, Santa Barbara, CA.

Roberts, M. R. and Paul, N. D. (2006). Seduced by the dark side: integrating molecular and ecological perspectives on the influence of light on plant defence against pests and pathogens. New Phytologist, 170, 677-699.

Rosenzweig, C., Elliott, J., Deryng, D., Ruane, A. C., Muller, C., Arneth, A., Boote, K. J., Folberth, C., Glotter, M., Khabarov, N., Neumann, K., Piontek, F., Pugh, T. A., Schmid, E., Stehfest, E., Yang, H. and Jones, J. W. (2014). Assessing agricultural risks of climate change in the 21st century in a global gridded crop model intercomparison. Proceedings of the National Academy of Sciences of the U.S.A., 111, 3268-3273. 
Sarwar, S. and Sarwar, M. (2018). Involvement of insects (Insecta: Artropoda) in spreading of plant pathogens and approaches for pests management. American Journal of Microbiology and Immunology, 3, 1-8.

Schuerger, A. C. and Brown, C. S. (1997). Spectral quality affects disease development of three pathogens on hydroponically grown plants. HortScience, 32, 96-100.

Shimoda, T., Ozawa, R., Sano, K., Yano, E. and Takabayashi, J. (2005). The involvement of volatile infochemicals from spider mites and from food-plants in prey location of the generalist predatory mite Neoseiulus californicus. Journal of Chemical Ecology, 31, 2019-2032.

Suzuki, N., Rivero, R. M., Shulaev, V., Blumwald, E., Mittler, R. (2014). Abiotic and biotic stress combinations. New Phytologist, 203: 32-43.

Thresh, J.M. (1982). Cropping practices and virus spread. Annual Review of Phytopathology, 20, 193-218.

Torr S. J., Hall D. R., Phelps R. J., Vale G. A. (1997). Methods for dispensing odour attractants for tsetse flies (Diptera: Glossinidae). Bulletin of Entomological Research, 87, 299-311.

United Nations, Department of Economic and Social Affairs (2015). World population predicted to reach 9.7 billion by 2050. Available at: http://www.un.org/en/development/desa/news/population/2015-report.html

van der Kraan, C and Ebbers, A. (1990). Release rates of tetradecen-1-ol acetates from polymeric formulations in relation to temperature and air velocity. Journal of Chemical Ecology, 16, $1041-1058$.

Vanachter, A., van Wambeke, E., van Assche, C. (1983). Potential danger for infection and spread of root disease of tomatoes in hydroponics. Acta Horticulturae, 133, 119-128. 
Wang, H., Jiang, Y. P., Yu, H. J., Xia, X. J., Shi, K., Zhou, Y. H., Yu, J. Q. (2010). Light quality affects incidence of powdery mildew, expression of defence-related genes and associated metabolism in cucumber plants. European Journal of Plant Pathology, 127, 125-35.

Wheeler, T. and Von Braun, J. (2013). Climate change impacts on global food security. Science, 341, 508-13.

Whipps, J. M. and Budge, S. P. (2000), Effect of humidity on development of tomato powdery mildew (Oidium lycopersici) in the glasshouse. European Journal of Plant Pathology, 106, 395-397.

Whitfield, A. E., Falk, B. W., Rotenberg, D. (2015). Insect vector-mediated transmission of plant viruses. Virology, 479-480, 278-289.

Yaku, A., Walter, G. H., Najar-Rodriguez, A. J. (2007). Thrips see red - flower colour and the host relationship of a polyphagous anthophilic thrips. Ecological Entomology, 32, 527-535.

Yano, S. (2004). Does Tetranychus urticae (Acari: Tetranychidae) use flying insects as vectors for phoretic dispersal? Experimental and Applied Acarology, 32, 243-248.

Yarwood, C. E. (1956). Humidity requirements of foliage pathogens. Plant Disease Reports, 40, 318-321.

Zinnen, T. M. (1988). Assessment of plant diseases in hydroponic culture. Plant Disease, 72, 96-99.

\section{FIGURE LEGENDS}

FIGURE 1: Vertical Farming systems present several considerations for pest and disease management, some shared with conventional protected horticulture and others unique to vertical farming. Pests and micro-organisms can enter the system via doorways (A) and ventilation systems. Gradients of parameters such as temperature (B) and light level (C) within the vertical farming system provide varied 
conditions for both the growth of plants and development of pests and disease. Whilst necessary to address such gradients and control humidity, air circulation (D) and rotating vertical farming systems can aid dispersal of fungal spores and could interrupt insect chemical communication. Humidity buildup between growth levels in vertical farming systems (E) can provide conditions conducive to disease development and pest movement and can lead to the formation of water droplets $(F)$ that further aid pest and disease dispersal through water splash. Insect pests may transfer between levels in the growth system by falling from upper levels $(G)$. The physical isolation of the different growth levels, however, may also provide a barrier to insect movement $(\mathrm{H})$ which may prove beneficial for pest species but could impact negatively on biocontrol efficacy. Disease can also spread through hydroponic nutrient solution (I). Light levels and the provision of artificial lighting (J) also influence crop growth, pest behaviour and pathogen lifecycles so must be chosen with care. Finally, consideration should also be given to plant spacing $(K)$ which influences humidity and physical transfer of pests. 
FIGURES

FIGURE 1.

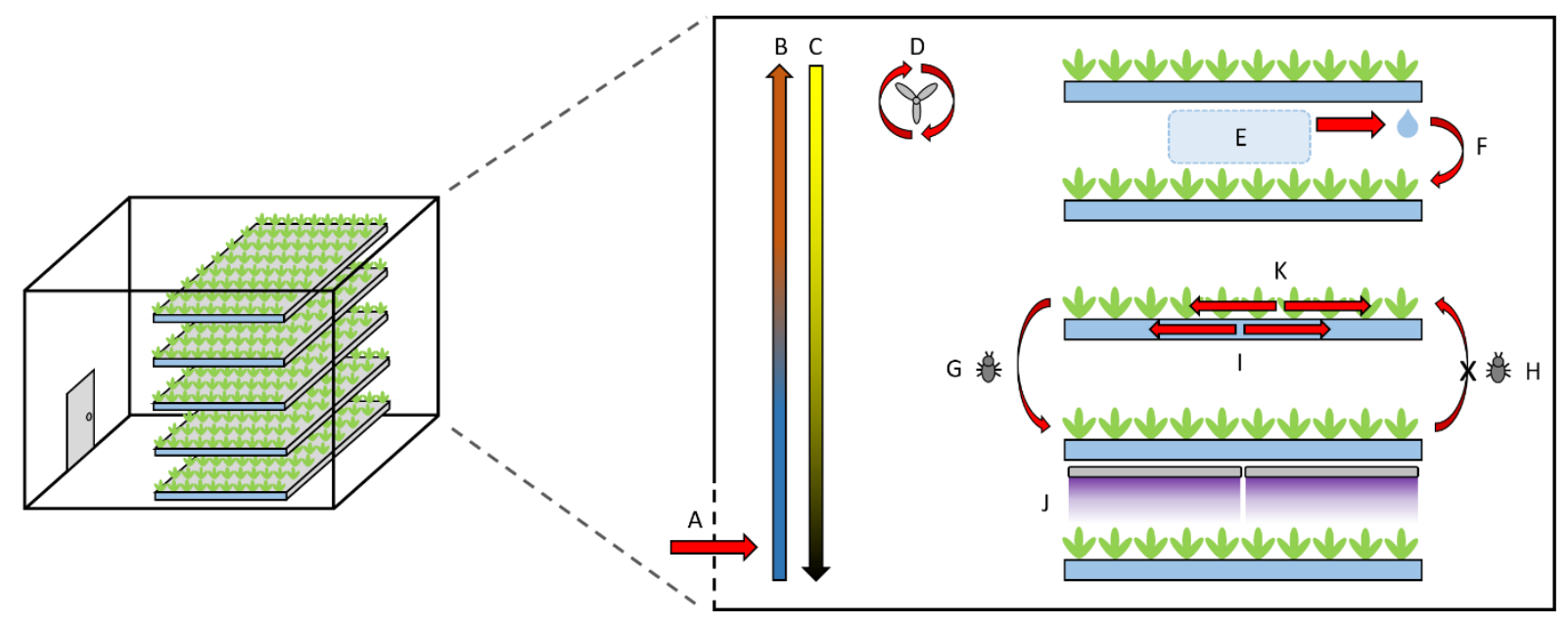

